Tersedia online di: http://ejournal-balitbang.kkp.go.id/index.php/bawal
e-mail:bawal.puslitbangkan@ @mail.com
BAWAL wIDYA RISET PERIKANAN TANGKAP
Volume 8 Nomor 3 Desember 2016
p-ISSN: 1907-8226
e-ISSN: 2502-6410
BAWAL
Nomor Akreditasi: $620 /$ AU2/P2MI-LIPI/03/2015
BAWAL

\title{
STRUKTUR UKURAN DAN PARAMETER POPULASI IKAN LEMADANG (Coryphaena hippurus Linnaeus, 1758 ) DI LAUT SULAWESI
}

\section{SIZE STRUCTURE AND POPULATION PARAMETERS OF DOLPHIN FISH (Coryphaena hippurus Linaeus, 1758) IN THE CELEBES SEA}

\author{
Umi Chodrijah*1 dan Duto Nugroho ${ }^{2}$ \\ ${ }^{1}$ Balai Penelitian Perikanan Laut, Muara Baru, Komplek Pelabuhan Perikanan Samudera, $\mathrm{x}$ \\ ${ }^{2}$ Pusat Penelitian dan Pengembangan Perikanan, Jl. Pasir Putih II, Ancol Timur Jakarta Utara, 14430, Indonesia \\ Teregistrasi I tanggal: 22 Juli 2016; Diterima setelah perbaikan tanggal: 06 Desember 2016; \\ Disetujui terbit tanggal: 08 Desember 2016
}

\begin{abstract}
ABSTRAK
Ikan lemadang (Coryphaena hippurus Linnaeus 1758.) dalam perdagangan internasional dikenal dengan nama mahi-mahi atau dolphinfish termasuk dalam family Coryphaenidae. Sebagai ikan pelagis, oseanik, bermigrasi jauh serta tersebar di perairan tropis dan subtropis di seluruh dunia. Penelitian ini bertujuan untuk mengkaji struktur ukuran dan parameter populasi ikan lemadang di Luat Sulawesi. Pengumpulan data dilakukan di Pelabuhan Perikanan Samudera Bitung, Sulawesi Utara, pada Februari-Desember 2012. Data perikanan dianalisis dari rekaman data pendaratan tahunan di Pelabuhan Perikanan Bitung pada kurun waktu 2004-2014. Analisis parameter laju pertumbuhan menggunakan pendekatan pergeseran modus, sedangkan perkiraan tingkat pemanfaatan dilakukan dengan menggunakan program FISAT II. Hasil penelitian menunjukkan bahwa sebaran panjang cagak ikan lemadang (Coryphaena hippurus) dari sampel 4160 ekor ikan tercatat panjang minimum 30 $\mathrm{cm}$ FL, panjang maksimum $121 \mathrm{cmFL}$ dan panjang-rata-rata 59,8 $\pm 1,39 \mathrm{~cm}$, dengan berat rata-rata sebesar 2,1 $\pm 1,52 \mathrm{~kg}$. Pola pertumbuhan bersifat isometrik dengan persamaan hubungan panjang-berat $\mathrm{W}=0,000003 \mathrm{~L}^{3,2203}$ $\left(\mathrm{r}^{2}=0,93\right)$. Pendugaan parameter populasi ikan lemadang di Laut Sulawesi diperoleh panjang asimtotik $(\mathrm{L} \infty)=$ $154 \mathrm{cmFL}$, kecepatan pertumbuhan $(\mathrm{K})=0,75$ per tahun dan umur pada saat ditetaskan $\left(\mathrm{t}_{0}\right)=0,25$ tahun. Mortalitas total (Z) adalah 4,37 per tahun dengan mortalitas alami (M) dan mortalitas penangkapan (F) masingmasing 0,97/tahun dan 3,40/tahun. Tingkat eksploitasi (E) ikan lemadang diperkirakan sebesar 1,28. Hal ini berarti tingkat pemanfaatan ikan lemadang di Laut Sulawesi berada pada status telah tereksploitasi tinggi.
\end{abstract}

Kata Kunci: Struktur ukuran; pertumbuhan; ikan lemadang; Laut Sulawesi

\section{ABSTRACT}

Mahi-mahi or dolphinfish (Coryphaena hippurus) are oceanic, highly migratory, and geographically exist in tropical and subtropical waters. This research aims to examine size structures and population parameter of mahi-mahi of the Celebes Sea. This research conducted in the Bitung fishing port during February to December 2012. The fisheries data from 2004 to 2014 periods used to examine the annual trend of catch landing. Growth parameters were analyzed based on length based by using modal progression analyses. The exploitation level measured by using FISAT II software. The results showed that the length distribution of fish during sampling periods ranged of $30 \mathrm{cmFL}$ to $121 \mathrm{cmFL}$. The average length was $59.8 \pm 1.39 \mathrm{~cm}$, with average weight of $2.1 \pm$ $1.52 \mathrm{~kg}$. Length and weight relationship followed equation of $W=0.000003 L^{3,2203}\left(r^{2}=0.9335\right)$. Population parameters included asymptotic length growth rate $\left(L^{\infty}\right)$ was $154 \mathrm{cmFL}$, growth rate $(K)=0.75$ per year and zero age $\left(t_{0}\right)$ was 0.25 years. The total mortality index $(Z)$ was 4.37 per year, natural mortality $(M)$ and fishing mortality $(F)$ were 0.97 per year and 3.40 per year, respectively. The estimated exploitation rate $(E)$ was 1.28 per year, this indicate that the status of mahi-mahi in the area of sampling were at moderate level.

Keywords: Size structures; growth; dolphin fish; Celebes Sea 


\section{PENDAHULUAN}

Ikan lemadang (Coryphaena hippurus Linnaeus, 1758) dalam perdagangan internasional dikenal dengan nama mahi-mahi atau dolphin fish. Klasifikasi taksonomik termasuk dalam marga Coryphaenidae. Ikan lemadang merupakan salah satu hasil tangkapan sampingan (bycatch) dari beberapa aktivitas perikanan yang menggunakan alat tangkap yang ditujukan untuk menangkap tuna, tongkol dan cakalang seperti pajeko (purse seine), huhate (pole and line) dan pancing ulur (hand line). Perairan Laut Sulawesi merupakan perairan yang berlokasi di berbatasan dengan Filipina dan memiliki potensi sumberdaya ikan pelagis besar termasuk ikan lemadang yang cukup banyak dan telah dimanfaatkan sejak berkembangnya penggunaan ketiga alat tangkap tersebut. Menurut De Metrio et al. (1997) dan Macías et al., (2000; 2012), ikan lemadang juga merupakan bycatch dari armada perikanan rawai tuna (longline).

Ikan lemadang menyebar di perairan tropis dan subtropis di seluruh dunia (Gibbs \& Collete, 1959 dalam Oxenford, 1998). Beberapa hasil penelitian menunjukkan bahwa jenis ini diduga mencapai ukuran panjang maksimum sekitar $162 \mathrm{~cm}$ dan berat 22,4 kg (Hutchins \& Swainston, 1986 dalam Smallwood et al., 2013). Karakteristik morfologis dicirikan oleh warna kuning emas pada bagian sisi, serta warna biru cerah dan hijau di bagian samping dan belakang. Ikan berjenis kelamin jantan dewasa memiliki dahi yang menonjol di bagian atas kepala, sedangkan betina memiliki kepala yang bulat (Collette, 1999). Statistik perikanan tangkap Indonesia tahun 2014 (DJPT, 2015) memperlihatkan bahwa spesies ini didaratkan sejumlah 11917 ton dan banyak ditangkap dengan alat tangkap pukat cincin (18\%), pancing ulur (20\%), tonda (33\%), terdapat di wilayah perairan yang dipengaruhi oleh karakteristik masa air oseanik yaitu perairan Laut Maluku, Selatan Jawa dan perairan Sulawesi (UNEP, 2005).

Penelitian tentang ikan lemadang telah banyak dilakukan di beberapa perairan samudera diantaranya di wilayah India, Mexico, Mediterania, Spanyol, Atlantik, Amerika. Di perairan Indonesia, ketersediaan data dan informasi hasil penelitian terhadap karakteristik biologi dan eksploitasi sumberdaya ikan lemadang masih sangat terbatas yaitu Nugraha \& Rahmat (2008); Triharyuni \& Prisantoso (2012); Ariawan (2015). Berdasarkan pertimbangan sifat ikan yang beruaya jauh hingga lintas samudera, maka penelitian mengenai populasi ikan lemadang sangat diharapkan untuk dilakukan oleh negaranegara yang dilaluinya termasuk Indonesia. Penelitian ini bertujuan untuk mengetahui karaketeristik dan struktur ukuran dan parameter populasi ikan lemadang yang tertangkap di Laut Sulawesi. Informasi yang dihasilkan sangat diperlukan sebagai bahan dasar pengelolaan ikan lemadang sehingga dapat dimanfaatkan secara berkelanjutan.

\section{BAHANDANMETODE Pengumpulan Data}

Pengambilan sampel ikan lemadang sebanyak 4.160 ekor yang dilakukan di Pelabuhan Perikanan Samudera Bitung pada Februari sampai dengan Desember 2012. Pengambilan data bulanan secara berkesinambungan dilakukan dengan bantuan tenaga enumerator. Data morfometrik ikan yaitu panjang cagak (diukur dengan ketelitian $1 \mathrm{~cm}$ ) dan berat (ditimbang hingga satuan $1 \mathrm{~kg}$ ) diukur untuk tiap individu ikan lemadang (Coryphaena hippurus). Selang frekuensi panjang dilakukan dengan kisaran $2 \mathrm{~cm}$ mengikuti ketentuan yang disarankan oleh organisasi pengelolaan perikanan regional kawasan Pasifik barat (Williams, 2014). Beberapa data pendukung terkait dengan perubahan volume produksi tahunan dianalisis berdasarkan data statistik perikanan tangkap wilayah Utara Sulawesi pada kurun waktu 2004 - 2014.

\section{Analisis Data}

Hubungan panjang-berat mengikuti persamaan umum $\mathrm{W}=\mathrm{aL}^{\mathrm{b}}$ dimana $\mathrm{W}=$ berat ikan $(\mathrm{kg})$ dan $\mathrm{L}=$ panjang ikan (cmFL). Parameter "a" adalah koefisien untuk berat terhadap panjang ikan dan "b" adalah parameter untuk bentuk tubuh ikan. Nilai "b" merupakan konstanta kubikal setiap spesies yang mendekati 3 untuk kelompok isometrik. Transformasi logaritmik terhadap persamaan tersebut menjadi:

$\log W=\log a+b \log L$

Faktor kondisi Fulton (Kn) merupakan indeks rasio berat terhadap panjang ikan yang digunakan untuk menggambarkan kondisi ikan terkait dengan ketersediaan nutrisi dan periode setelah pemijahan pada satu kurun waktu dan di lokasi yang relatif sama. Indeks Kn diturunkan dalam persamaan Fulton (1904) dalam Froese (2006) sebagai berikut:

$\mathrm{Kn}=\frac{100 \times \mathrm{W}}{\mathrm{L}^{3}}$

Dimana:

$\mathrm{Kn}=$ indeks faktor kondisi Fulton

$\mathrm{W}=$ berat $(\mathrm{g})$

$\mathrm{L}=$ panjang $(\mathrm{cmFL})$

Parameterisasi populasi dilakukan dengan pendekatan pengkajian stok ikan secara umum dan khususnya di kawasan tropis yang dikemukakan oleh (Pauly, 1983; Sparre \& Venema, 1999; King, 1995). Pendugaan parameter pertumbuhan dari Von Bertalanffy yaitu panjang total asimtotik ( $\mathrm{L}_{0}$ ) dan koefisien pertumbuhan (K) dihitung menggunakån pendekatan pergeseran bulanan modus ukuran ikan. Setiap modus diturunkan dengan metoda Batacharya (1967) dalam Sparre \& Venema (1999) mewakili 
kelompok umur ukuran yang tertangkap. Perkiraan kohor pada setiap pengukuran dilakukan melalui program FISAT II. Estimasi pertumbuhan dihitung dengan menggunakan persamaan linier seperti dikemukakan oleh Gulland dan Holt (1959) dalam Sparre \& Venema (1999):

$$
\frac{\Delta L}{\Delta t}=a+\mathrm{b} * \mathrm{~L}(\mathrm{t})
$$

Hubungan linier diturunkan dari persamaan von Bertalanffy sebagai berikut:

$$
\frac{\Delta L}{\Delta t}=\mathrm{K} *(\mathrm{~L} \infty-\mathrm{Lt})
$$

Dimana:

$\mathrm{K}=-\mathrm{b}$ dan $\mathrm{L} \infty=-\mathrm{a} / \mathrm{b}$

Estimasi pertumbuhan dihitung melalui rata laju pergeseran modus melalui persamaan:

$\bar{L}=\frac{L(t+\Delta t)+L(t)}{2}$

Pendugaan nilai $\mathrm{t}_{\mathrm{o}}$ (umur pada saat 0 tahun berdasarkan persamaan Pauly (1984) yaitu

$\log \left(-t_{0}\right)=0,3922-0,2752 \log \left(L^{\infty}\right)-1.038 \log (K)$

Laju mortalitas alami (M) diduga dengan mengaplikasikan model empiris dari Pauly (1980) yaitu :

$\log (M)=-0,0066-0,279 * \log \left(L^{\infty}\right)+0,6543 * \log$

$$
\text { (K)+0,4634* } \log (\mathrm{T}) \text {. }
$$

Tabel 1. Ringkasan rerata panjang (cmFL) bulanan ikan lemadang tahun 2012

Table 1. Summary of monthly average length of dolphin fish in 2012

\begin{tabular}{llllllllllll}
\hline $\begin{array}{l}\text { Parameter/ } \\
\text { Parameter }\end{array}$ & Feb & Mar & Apr & Mei & Jun & Jul & Agu & Sep & Okt & Nop & Des \\
\hline Rerata & 60 & 62 & 56 & 57 & 46 & 68 & 56 & 61 & 59 & 62 & 65 \\
Median & 58 & 53 & 53 & 53 & 45 & 68 & 54 & 60 & 56 & 61 & 64 \\
Modus & 48 & 46 & 53 & 53 & 43 & 73 & 53 & 50 & 53 & 50 & 60 \\
simp. Baku & 14,0 & 18,8 & 11,1 & 13,0 & 4,6 & 12,9 & 11,1 & 13,3 & 10,4 & 9,5 & 11,6 \\
Varians & 196.0 & 352.9 & 124.1 & 169.5 & 21.0 & 165.8 & 122.2 & 176.8 & 109.0 & 91.2 & 134.1 \\
Minimum & 30 & 36 & 35 & 34 & 38 & 35 & 32 & 32 & 39 & 38 & 43 \\
Maximum & 93 & 121 & 102 & 106 & 67 & 115 & 99 & 112 & 96 & 96 & 110 \\
Jumlah (n) & 406 & 422 & 496 & 456 & 131 & 429 & 437 & 390 & 431 & 419 & 243 \\
\hline
\end{tabular}

Sebaran data hubungan panjang bobot bulanan diplot seperti pada Gambar 1 dengan persamaan yang diperlihatkan pada Tabel 2. Koefisien a berkisar antara $1.00 \mathrm{e}^{-05}-5.00 \mathrm{e}^{08}$ sedangkan koefisien b berkisar antara $2,9164-4,2895$.

Analisis hubungan panjang berat ikan lemadang terhadap semua sample terkumpul selama kurun waktu

\section{Dimana :}

$\mathrm{L}^{\infty}=$ panjang asimtotik (cmFL)

$\mathrm{K}=$ kecepatan pertumbuhan

$\mathrm{T}=$ rataan suhu lingkungan perairan $=30^{\circ} \mathrm{C}(\mathrm{BPPL}$, 2012).

Koefisien mortalitas total (Z) diperoleh dari kurva hasil tangkapan berdasarkan panjang (length converted catch curve) (Pauly, 1983) yang perhitungannya menggunakan paket program FISAT (Gayanilo et al., 2005). Koefisien mortalitas penangkapan (F) dihitung dari persamaan:

$\mathrm{F}=(\mathrm{Z}-\mathrm{M})$

Laju eksploitasi (E) dihitung menggunakan persamaan:

$\mathrm{E}=\mathrm{F} / \mathrm{Z}$

\section{HASIL DAN BAHASAN \\ Hasil}

\section{Struktur Ukuran Panjang}

Pengukuran terhadap 4.160 ekor ikan lemadang diperoleh panjang minimum $30 \mathrm{~cm}$ FL dan panjang maksimum $121 \mathrm{cmFL}$. Ukuran panjang minimum (30 cmFL) ditemukan pada bulan Februari sedangkan ukuran maksimum (121 cm FL) ditemukan pada bulan Maret. Sedangkan rerata panjang terendah sebesar $46 \mathrm{cmFL}$ pada bulan Juni dan tertinggi $68 \mathrm{cmFL}$ pada bulan Juli. Hasil observasi panjang cagak setiap bulannya disajikan pada Tabel 1 sedangkan histogram sebaran frekuensi panjang bulanan pada Lampiran 2 . penelitian dihasilkan persamaan $\mathrm{W}=0,00001 \mathrm{~L}^{3,2203}\left(\mathrm{r}^{2}=\right.$ 0,9335 dengan nilai $b=3,2203$ (Gambar 3). Setelah dilakukan uji t dengan tingkat kepercayaan $95 \%$, diperoleh nilai $\mathrm{t}_{\text {hitung }}=1,601193$ lebih kecil dari $\mathrm{t}_{\text {tabel }}=$ 1,64; artinya peningkatan pertambahan berat sebanding dengan pertumbuhan panjangnya. 


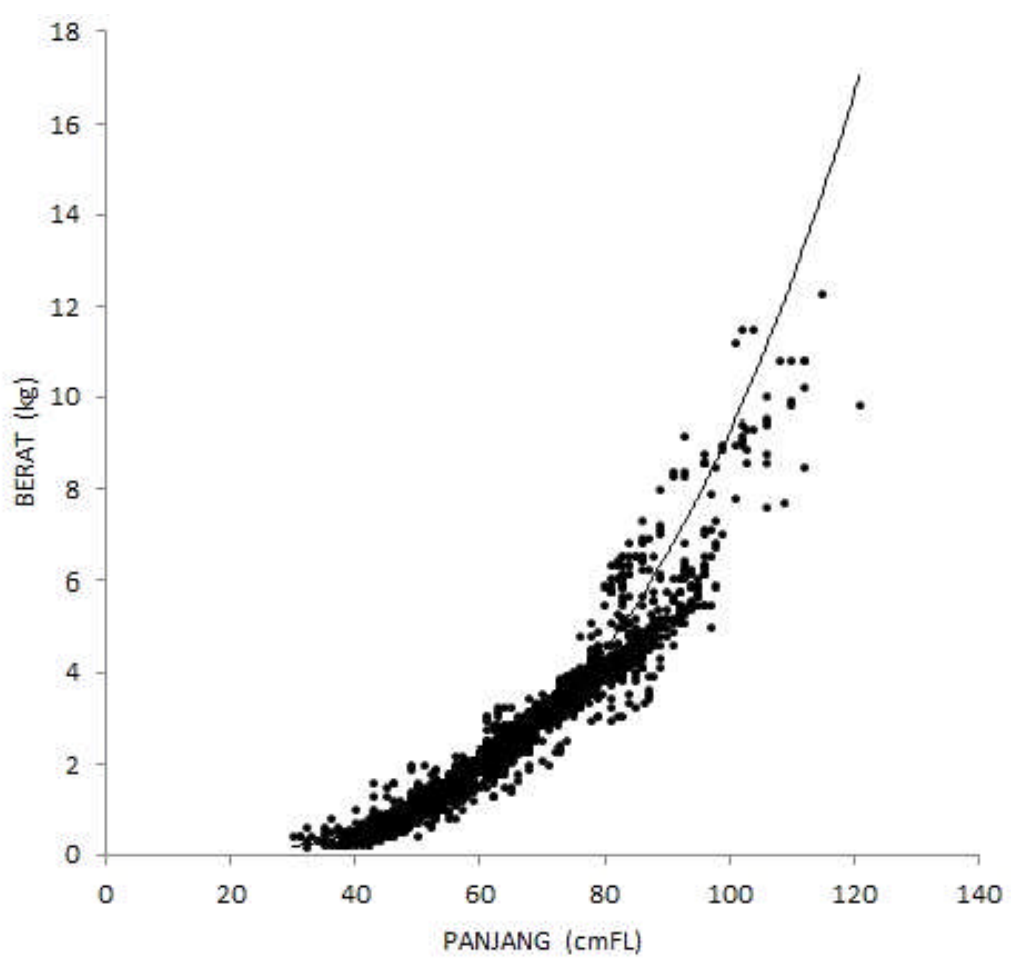

Gambar 1. Hubungan panjang dan bobot ikan lemadang di perairan Laut Sulawesi.

Figure 1. Length and weight relationship of Coryphaena hippurus in Celebes Sea.

Table 2. Pola pertumbuhan panjang - berat, bulanan (anuari - Desember 2012

Table 2 Monthly pattern of length - weight January - December 2012

\begin{tabular}{lcc}
\hline Bulan/month & $\begin{array}{c}\text { Hubungan panjang - berat/Leght weight } \\
\text { relationship }\end{array}$ & $\begin{array}{c}\text { Koefisien regresi/ } \\
\text { Regrensi coefficient }\end{array}$ \\
\hline Februari & $\mathrm{W}=6 \mathrm{E}-06 \mathrm{~L}^{3.0515}$ & $\mathrm{R}^{2}=0,9328$ \\
Maret & $\mathrm{W}=3 \mathrm{E}-06 \mathrm{~L}^{3.2384}$ & $\mathrm{R}^{2}=0,9195$ \\
April & $\mathrm{W}=6 \mathrm{E}-06 \mathrm{~L}^{3.0652}$ & $\mathrm{R}^{2}=0,9245$ \\
Mei & $\mathrm{W}=7 \mathrm{E}-06 \mathrm{~L}^{3.0266}$ & $\mathrm{R}^{2}=0,9525$ \\
Juni & $\mathrm{W}=5 \mathrm{E}-08 \mathrm{~L}^{4.2895}$ & $\mathrm{R}^{2}=0,8793$ \\
Juli & $\mathrm{W}=1 \mathrm{E}-05 \mathrm{~L}^{2.9164}$ & $\mathrm{R}^{2}=0,9525$ \\
Agustus & $\mathrm{W}=7 \mathrm{E}-07 \mathrm{~L}^{3.5926}$ & $\mathrm{R}^{2}=0,9545$ \\
September & $\mathrm{W}=3 \mathrm{E}-06 \mathrm{~L}^{3.2519}$ & $\mathrm{R}^{2}=0,9659$ \\
Oktober & $\mathrm{W}=2 \mathrm{E}-06 \mathrm{~L}^{3.3548}$ & $\mathrm{R}^{2}=0,9545$ \\
Nopember & $\mathrm{W}=3 \mathrm{E}-06 \mathrm{~L}^{3.2772}$ & $\mathrm{R}^{2}=0,9703$ \\
Desember & $\mathrm{W}=1 \mathrm{E}-05 \mathrm{~L}^{2.922}$ & $\mathrm{R}^{2}=0,9545$ \\
\hline
\end{tabular}

Besaran indeks Fulton selama penelitian diperlihatkan pada Gambar 2. Sebaran nilai bulanan tersebut memberikan pola yang berbeda, nilai kisaran rerata bulanan faktor kondisi $0.72-0.92$, sedangkan nilai terendah (0.27) ditemukan pada bulan Maret dan tertinggi (2.01) pada bulan Mei. Rentang nilai terbesar terjadi pada bulan Februari - Mei, hal ini memberikan indikasi bahwa ikan berada pada kondisi lingkungan yang relatif baik dan diduga merupakan musim pemijahan. Rentang nilai kemudian menurun pada kurun waktu Juni - Desember 2012 yang memberikan indikasi bahwa kondisi biologi ikan yang tumbuh berada pada lingkungan maupun periode reproduksi yang relatif stabil sehingga tidak mempengaruhi struktur morphologi dan bobot ikan seperti dikemukakan oleh Heincle (1908) dalam Froese (2006) dan Nash et al., (2006). 


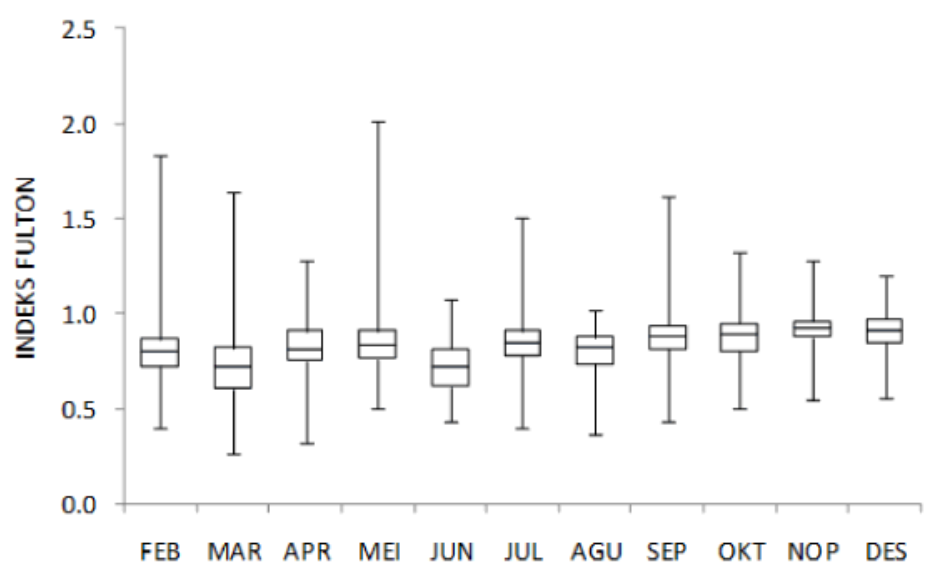

Gambar 2. Perubahan bulanan indeks Fulton bulan Februari - Desember 2012.

Figure 2. Monthly changes of Fulton indices during February-December 2012.

Analisis dengan pendekatan pergeseran modus ukuran ikan yang tertangkap kemudian digrafikan melalui regresi antara perubahan ukutan panjang per satuan waktu $(d L /$ $d t$ ) dan rerata modus $\bar{L}$ (ukuran panjang ikan (Sparre dan Venema 1999). Analisis grafikal tersebut menghasilkan estimasi nilai panjang asimtotik $\left(\mathrm{L}^{\infty}\right)$ sebesar $154 \mathrm{cmFL}$ (Gambar 3) dan laju pertumbuhan $(\mathrm{K})=0,75$ pertahun. Kurva pertumbuhan von Bertalanffy diperlihatkan pada Gambar 4.

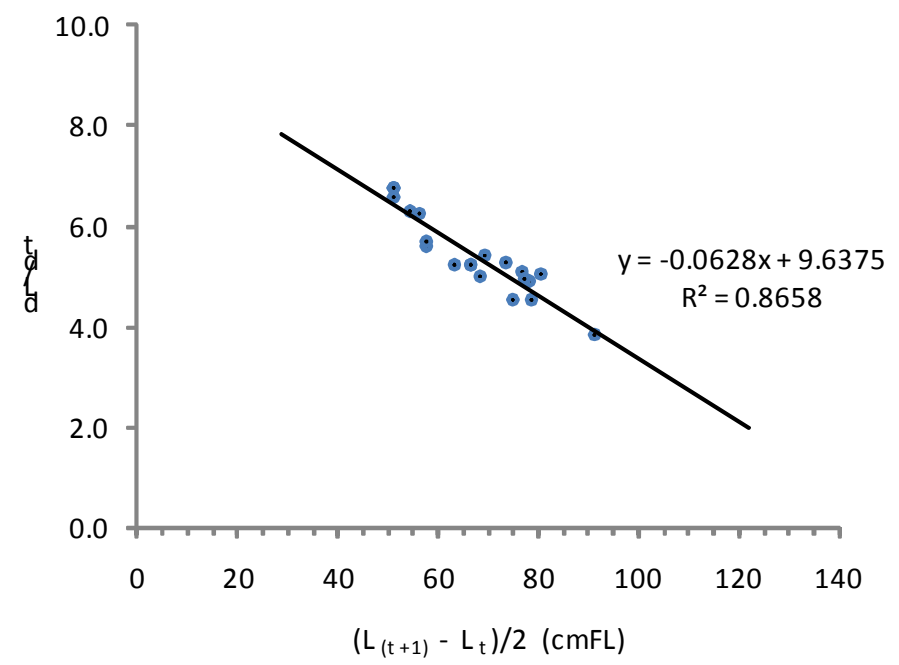

Gambar 3. Estimasi K dan $\mathrm{L}^{\infty}$ dengan Gulland dan Holt plot.

Figure 3. Estimating on $K$ and $L^{\infty}$ with Gulland and Holt plot.

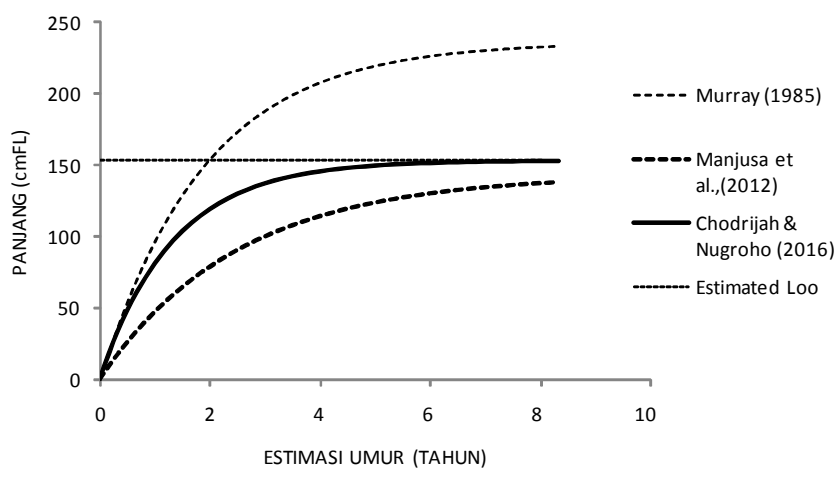

Gambar 4. Kurva pertumbuhan lemadang.

Figure 4. Growth curve of dolphin fish. 
Mengacu pada estimasi umur berdasarkan ukuran panjang melalui persamaan von Bertalanffy dan sebaran normal frekuensi panjang maka dengan menggunakan pemisahan modus mengikuti metoda Batcharya (1967) dalam Sparre \& Venema (1998) diduga kelompok ikan terukur terdiri dari 4 kelompok umur tahunan seperti diperlihatkan pada Gambar 5.

Parameter mortalitas alami (M) dihitung dengan mempertimbangkan rata-rata suhu tahunan di perairan
Laut Sulawesi yaitu sebesar $30^{\circ} \mathrm{C}$ (BPPL, 2012) sebagai peubah, dalam persamaan empiris yang dikemukakan oleh Pauly (1980). Diperlukan nilai M ikan lemadang adalah 0,97 per tahun. Mortalitas akibat penangkapan (F) didapatkan dari persamaan $\mathrm{F}=\mathrm{Z}$-M. Estimasi besaran nilai total mortalitas $(\mathrm{Z})$ menggunakan kurva ukuran hasil tangkapan yang dilinierkan yaitu sebesar 4,37 per tahun, (Gambar 6), exlpoitasi (E) ini merupakan perbandingan antara nilai $\mathrm{F}$ dan $\mathrm{Z}$ berdasarkan nilai yang diperoleh maka nilai E dapat dihitung yaitu sebesar 3,40.

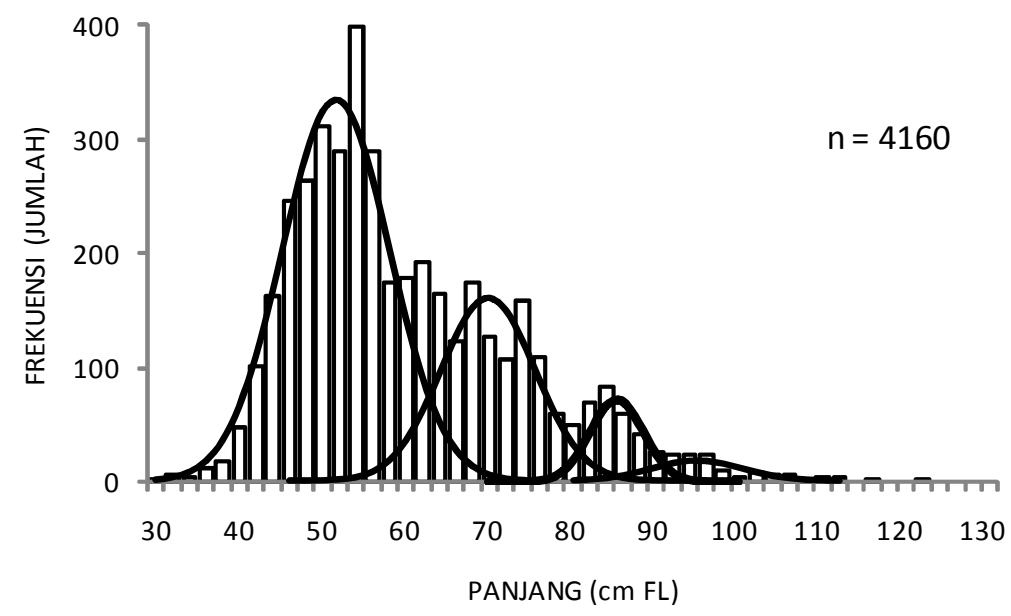

Gambar 5. Sebaran ukuran panjang dan estimasi kelompok umur ikan lemadang.

Figure 5. Frequency distribution and its estimated cohorts.

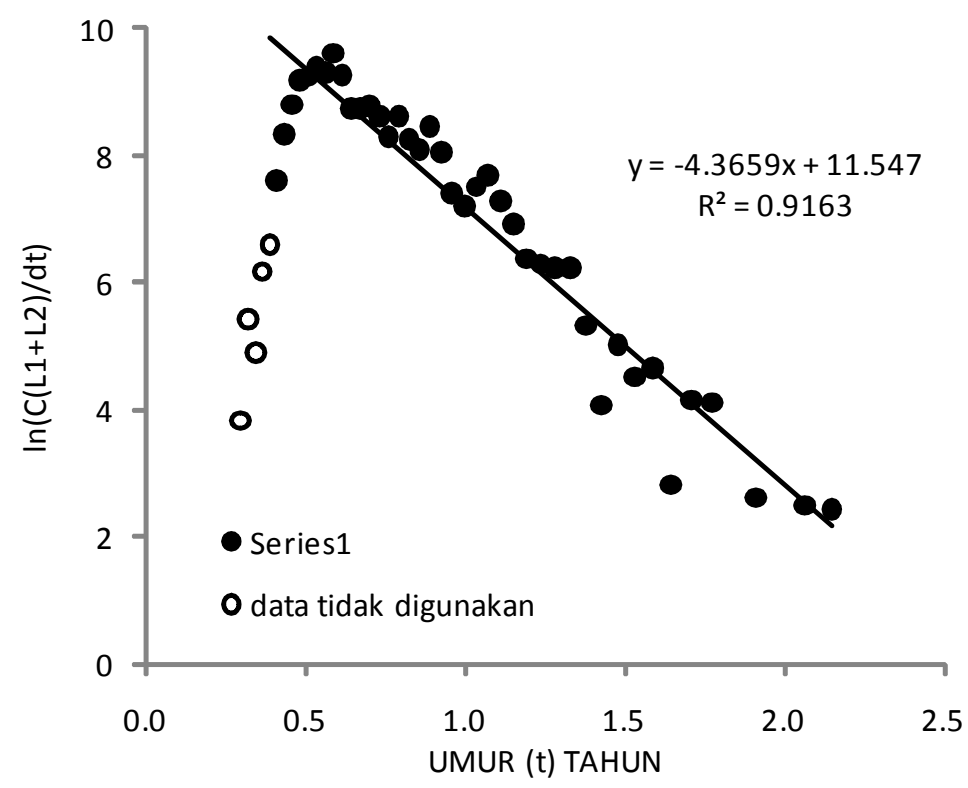

Gambar 6. Estimasi nilai Z sebagai slope kurva hasil tangkapan ikan lemadang (Coryphaena hippurus) di Laut Sulawesi. Figure 6. The estimated value of total mortality $(Z)$ of mahi-mahi ((Coryphaena hippurus) in Celebes Sea

Pemanfaatan sumber daya ikan lemadang berdasarkan statistik perikanan tangkap di Utara Sulawesi dalam kurun waktu 2004 hingga 2014 memperlihatkan kecenderungan yang meningkat pada tahun 2004 hingga 2012 kemudian menurun secara bertahap pada tahun sesudahnya. (Gambar 7). 


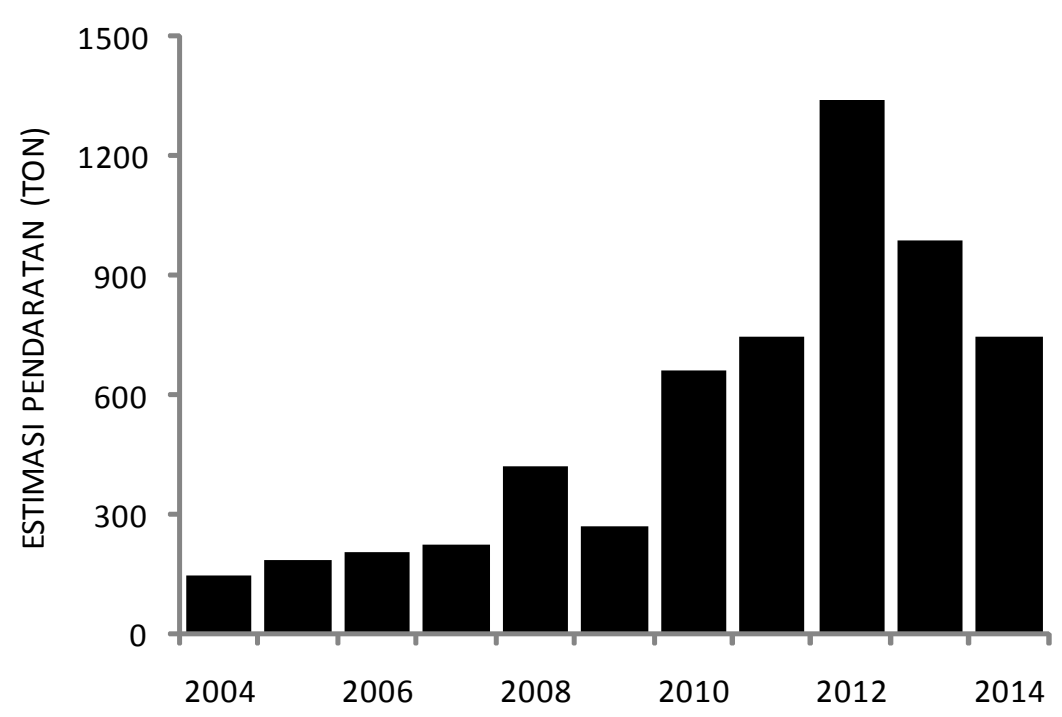

Gambar 7. Estimasi pendaratan tahunan ikan lemadang di kawasan Utara Sulawesi.

Figure 7. Estimation on dolphin fish landing data in North of Sulawesi.

\section{Bahasan}

Hasil penelitian menunjukkan bahwa kisaran ukuran ikan lemadang yang tertangkap huhate dan pancing ulur memiliki panjang minimum $30 \mathrm{~cm}$ FL dan maksimum 121 cmFL. Ukuran tersebut lebih kecil bila dibandingkan dengan hasil penelitian sebelumnya. Menurut Massuti \& MoralesNin (1997) panjang ikan lemadang di perairan Majorcan, Mediterania berkisar antara 60-120 cmFL. Alejo-Plata et al . (2011) melaporkan bahwa $C$. hippurus di perairan Teluk Mexico memiliki kisaran panjang 20,5-129 cmFL (betina) dan 25,5-152 cmFL (jantan). Selanjutnya Rivera-Betancourt (1994) dalam Oxenford, (1998) menyebutkan bahwa di perairan Puerto Rico, C. hippurus mempunyai kisaran panjang Antara 43-148 cmFL. Perbedaan kisaran panjang ini diduga karena perbedaan alat tangkap yang digunakan dan kondisi lingkungan perairan setempat serta ketersediaan makanan. Dilaut Sulawesi ikan lemadang banyak ditangkap dengan huhate dan pancing yang memiliki selektivitas tinggi. Kondisi lingkungan yang lebih bersifat perairan pantai merupakan bagian dari ruaya dan variasi intensitas penangkapan, diduga telah berlangsung sangat intensif dengan nilai laju eksploitasi yang tinggi.
Hubungan panjang dan berat ikan lemadang di Laut Sulawesi (tanpa membedakan jenis kelamin) diperoleh persamaan $\mathrm{W}=0,000003 \mathrm{~L}^{3,2203}\left(\mathrm{r}^{2}=0,9335\right)$ dengan nilai $\mathrm{b}=$ 3,2203 . Setelah dilakukan uji-t dengan tingkat kepercayaan $95 \%$, diperoleh nilai $\mathrm{t}_{\text {hitung }}=1,601$ lebih kecil dari $\mathrm{t}_{\text {tabel }}=$ 1,640 yang artinya peningkatan pertambahan berat sebanding dengan pertumbuhan panjangnya. Hal ini dapat disimpulkan bahwa ikan lemadang mempunyai pola pertumbuhan isometrik dengan nilai $b=3(b=3,2203)$, yang menunjukkan pertumbuhan bobot seiring dengan pertambahan panjangnya. Dibandingkan dengan hasil penelitian lainnya ternyata nilai a dan b hasil penelitian ini berbeda dengan hasil penelitian yang dilakukan di kawasan yang berbeda (Tabel 3). Menurut Gulland (1983) dan Sparre \& Venema (1999), variasi nilai b ini disebabkan berbagai faktor seperti suhu, salinitas, makanan (kuantitas, kualitas dan ukuran), jenis kelamin, tahap kematangan gonad dan kelestarian habitat. Sedangkan Richard et al., (2012) mengemukakan ikan yang melakukan ruaya jauh sering kali melewati berbagai kondisi lingkungan yang berada dalam batas toleransinya dan akan berakibat pada pola dan laju pertumbuhannya.

Tabel 3. Parameter a dan b pada beberapa hubungan panjang bobot ikan lemadang Table 3. Value of $a$ and $b$ parameters on the several leght-weight relationship

\begin{tabular}{llll}
\hline Lokasi/Location & \multicolumn{1}{c}{ "a" } & "b" & Penulis/Author \\
\hline Puerto Rico & $3.02 \mathrm{E}-08$ & 3,49 & Perez et al., (1992) \\
Cuba & $3.21 \mathrm{E}-05$ & 2,67 & Garcia-Arteaga et al., (1997) \\
Barbados & $1.45 \mathrm{E}-08$ & 2,91 & Oxenford (1985) \\
Meksiko & $2.446 \mathrm{E}-05$ & 2,75 & Fernandez et al., 2015 \\
India & $3.60 \mathrm{E}-03$ & 3,21 & Macias et al.,(2012) \\
Laut Sulawesi & $3.00 \mathrm{E}-06$ & 3,22 & Penelitian ini (Present study) \\
\hline
\end{tabular}


Analisis dengan pergeseran modus ukuran panjang, diperoleh nilai panjang asam asimtotik $(\mathrm{L} \infty) 154 \mathrm{cmFL}$ dengan laju pertumbuhan sebesar 0,75 per tahun. Nilai ini berbeda dengan estimasi panjang asimtotik ikan lemadang yang ditemukan di perairan India, yaitu 194,24 (Manjusha et al., 2012). Perbedaan karakteristik lingkungan terkait dengan kemampuan asimilatif individu ikan terhadap perubahan faktor abiotik dan biotik (Weatherley, 2011). Perbedaan produktivitas perairan, laju exploitasi dan proses ruaya ikan diduga menjadi faktor utama perbedaan karakteristik biologis ikan lemadang (Farrell, 2014).

Menurut Pauly. (1980) dalam Sparre \& Venema (1999), nilai $\mathrm{K}$ merupakan suatu parameter yang menentukan seberapa cepat ikan mencapai panjang asimtotiknya. Ikan dengan nilai $\mathrm{K}$ yang rendah pada umumnya memiliki umur panjang. Peneliti Manjusha et al., (2012) yang memperoleh kecepatan pertumbuhan ikan lemadang di India 0,40/tahun. Beberapa peneliti lain memperoleh nilai berbeda (Tabel4).

Tabel 4. Panjang asimtotik (Lo) dan laju pertumbuhan (K) ikan lemadang dari berbagai lokasi penelitian Table 4. Asymptotic length $\left(L_{\infty}\right)$ and growth rate $(K)$ of dolphin fish from several locations

\begin{tabular}{lccl}
\hline \multicolumn{1}{c}{ Lokasi / Location } & K(tahun / year $)$ & L $\infty(\mathbf{c m})$ & \multicolumn{1}{c}{ Penulis /Author } \\
\hline St. Lucia & 0,532 & 236,10 & Murray (1985) \\
India & 0,400 & 194,25 & Manjusha et al. (2012) \\
L. Tengah & 1.54 & 126.6 & Gatt et al, (2015) \\
Meksiko & 0.874 & 231.65 & Fernandez et al. (2015) \\
Laut Sulawesi & 0,754 & 153.50 & Chodrijah \& Nugroho (2016) \\
\hline
\end{tabular}

Untuk mengetahui perkiraan laju pemanfaatan, perhitungan laju kematian karena penangkapan $(\mathrm{F})$ bervariasi menurut keragaman upaya penangkapan (f) setiap tahunnya. Nilai F menunjukkan seberapa besar dan meningkatnya tekanan penangkapan (fishing pressure) terhadap stok ikan di suatu perairan (Suman \& Boer, 2005);

Jika nilai mortalitas alami dari ikan lemadang, $\mathrm{M}=0,97$ per tahun dan mortalitas penangkapan $\mathrm{F}=3.40$ per tahun maka diperoleh nilai tingkat eksploitasi $\mathrm{E}=1.28$. Nilai laju eksploitasi (E) tersebut mengindikasikan bahwa tingkat eksploitasi ikan lemadang di perairan Laut Sulawesi telah berada pada kategori sangat tinggi. Pauly et al., (1984) menyebutkan bahwa nilai laju eksploitasi yang rasional dan lestari di suatu perairan berada pada nilai $\mathrm{E}<0,5$ atau paling tinggi pada nilai $\mathrm{E}=0,5$.

\section{KESIMPULAN}

Penelitian ikan lemadang (Coryphaena hippurus) di Laut Sulawesi sebanyak 4.226 ekor diperoleh panjang minimum $30 \mathrm{~cm}$ FL, panjang maksimum $121 \mathrm{cmFL}$, berada pada umur antara 6 bulan hingga 4 tahun. Diperoleh ratarata ukuran panjang sebesar $59,3 \mathrm{cmFL}$ atau berumur sekitar 1 tahun. Eksploitasi tertinggi berada pada kelompok umur muda. Pola pertumbuhan ikan bersifat isometrik dengan persamaan $\mathrm{W}=0,000003 \mathrm{~L}^{3,2203}\left(\mathrm{r}^{2}=0,9335\right)$. Pendugaan parameter populasi ikan lemadang diperoleh panjang $\operatorname{asimtotik}\left(\mathrm{L}^{\infty}\right)=154 \mathrm{cmFL}, \operatorname{kecepatan} \operatorname{pertumbuhan}(\mathrm{K})=$ 0,75 per tahun dan umur pada saat ditetaskan $\left(\mathrm{t}_{0}\right)=0,24998$ tahun. Mortalitas total (Z) adalah 4.37 per tahun dengan mortalitas alami (M) dan mortalitas penangkapan (F) masing-masing 0,97/tahun dan 3.40/tahun. Perkiraan tingkat eksploitasi (E) ikan lemadang adalah 1.28. Hal ini berarti tingkat pemanfaatan ikan lemadang di Laut Sulawesi dalam status dengan kategori tinggi.

\section{PERSANTUNAN}

Tulisan ini merupakan bagian dari kegiatan penelitian distribusi dan Kelimpahan Sumberdaya Ikan Pelagis Besar di WPP 716 Laut Sulawesi dan WPP 712 Laut Jawa pada Balai Penelitian Perikanan Laut Muara Baru, Jakarta Tahun Anggaran 2012.

\section{DAFTAR PUSTAKA}

Anonimous. (1982). United Nations Convention on the Law of the Sea. 2002 p. www.un.org/depts/los/ convention_agreements/text s/unclos/ unclos_e.pdf; diunduh 28 Juni 2016.

Ariawan. (2015). Analisis hasil tangkapan pancing ulur (hand line) pada rumpon portable di perairan selatan Palabuhanratu (p. 27), Jawa Barat. Skripsi. FPIK IPB.

BPPL. (2012). Laporan akhir. Penelitian distribusi dan kelimpahan sumberdaya ikan pelagis besar di WPP716 Laut Sulawesi dan WPP-712 Laut Jawa. Pusat 
Penelitian Pengelolaan Perikanan dan Konservasi Sumberdaya Ikan. Badan Litbang Kelautan dan Perikanan.

Collette, B.B. (1999). Coryphaenidae, Dolphinfishes ("dolphins"), In FAO species identification guide for fishery purposes (p. 2656-2658). The living marine resources of the western central Pacific. Volume 4. Bony fishes Part 2 (Mugilidae to Carangidae). Carpenter, K. E., Niem, V. H. (eds), FAO, Rome, Italy.

Collette, B., Acero, A., Amorim, A.F., Boustany, A., Ramirez, C.C. Cardenas, G., ............... Yanez, E. (2011). Coryphaena hippurus. The IUCN Red List of Threatened Species 2011: e.T154712A4614989. http://dx.doi.org/10.2305/ IUCN.UK.2011-2. RLTS.T154712A4614989.en. Downloaded on 28 June 2016.

De Metrio, G., Cacucci, M., Sion, L., Potoschi, A., Cannavó, G., Romeo, T..........Kapiris, C. (1997). Contract CEE N ${ }^{\circ}$ 94/079. Catches of juvenile bluefin tuna and swordfish during the albacore long-line fishery in the Mediterranean. Final Report. 1-45.

Direktorat Jenderal Perikanan Tangkap (DJPT). (2015). Statistik perikanan tangkap menurut provinsi (p. 356). Kementerian Kelautan dan Perikanan.

Farrell, E.R., Boustany, A.M., Halpinb P.N., Hammond, D.L. (2014). Dolphinfish (Coryphaena hippurus) distribution in relation to biophysical ocean conditions in the northwest Atlantic. Fisheries Research. 151, 177-190.

Fernández, M.S., Márquez, J.A.M., Cabello, M.G. \& Barr, E.E. (2015). Age and growth of the Dolphinfish Coryphaena hippurus in the coast of Oaxaca and Chiapas, Mexico. Revista de Biología Marina y Oceanografía. 50(3), 491-505, DOI: 10.4067/S071819572015000400008

Froese R. (2006). Cube law, condition factor and weightlength relationships: history, meta-analysis and recommendations. J. Appl. Ichthyol. 22, 241-253.

Gatt, M., Dimech, M. \& Schembril, P.J. (2015). Age, Growth and Reproduction of Coryphaena hippurus
(Linnaeus, 1758) in Maltese Waters, Central Mediterranean. Medit. Mar. Sci., 16(2), 334-345.

Gayanilo, F.C.Jr., Sparre, P. \& Pauly, D. (2005). FAOICLARM Stock Assessment Tools II (FiSAT II) (p. 168). Revised version. User's guide. FAO Computerized Information Series (Fisheries). No. 8, Revised version. Rome, FAO. 2005.

Gulland, J.A. (1983). Fish stock assessment (p. 233). A manual of Basic Methods. John Wiley \& Sons. Chicester.

King, M. (1995). Fisheries biology: Assessment and management (p. 341). Fishing News Books.

Massuti, E., \& Morales-Nin, B. (1997). Reproductive biology of dolphin-fish (Coryphaena hippurus L.) off the island of Majorca (western Mediterranean). Fisheries Research, 30, 57-65.

Macías, D., Báez, J. C., Barcelona, S.G., \& de Urbina, J.M.O. (2012). Length-weight relationship of dolphinfish by-caught In large pelagic longline fisheries Of the spanish Mediterranean. Collect. Vol. Sci. Pap. ICCAT. 68(3), 1261-1264.

Macías, D., \& de la Serna, J.M. (2000). By-catch composition in the Spanish Mediterranean longline gears. Abstract book of "Forth European Elasmobranch Association Meeting" Livorno, 27 30 September.

Manjusha, S. Kurup, B.M., Rajisha, R., Diana, B., Saravannane, N., Veloorkirakathi \& Sanjeevan, N. (2012). Studies on population characteristics of Coryphaena hippurus, (L) (Pisces: Perciformes) from Indian waters. Journal of Biodiversity and Environmental Sciences (JBES) ISSN: 2220-6663 (Print) 2222-3045 (Online), 2(3), 72-82.

Murray, P.A. (1985). Growth and mortality in the dolphinfish Coryphaena hippurus caught off Saint Lucia, W.I. In WECAFC (ed) (p. 147-153). National reports and selected papers presented at the fourth session of the Working Party on assessment of marine fishery resources. 
Nash, R.D.M., Valencia, A.H., \& Geffen A.J. (2006). The Origin of Fulton's Condition Factor. Setting the Record Straight. Fisheries. 31(5), 236-238.

Nugraha, B. \& Rahmat, E. (2008). Status perikanan huhate (Pole and Line) di Bitung. Sulawesi Utara. $J$. Lit. Perik. Ind. 14(3), 311-318.

Oxenford, H.A. (1985). Biology of the dolphin Coryphaena hippurus and its implications for the Barbadian fishery (p. 366). Ph.D. Thesis. University of the West Indies. Cave Hill. Barbados.

Oxenford, H.A. (1998). Biology of the dolphinfish (Coryphaena hippurus) in the western central Atlantic: a review. Scientia Marina. 63(3-4), 277301.

Pauly, D. (1980). On the interrelationship between natural mortality, grwoth parameters, and mean environmental temperature in 175 fish stocks. J. Com. CIEM.39(2), 175-192.

Pauly, D. (1983). Some simple methods for the 1983 assessment of tropical fish stocks. FAO Fish.Tech.Pap., (234), 52.

Pauly, D., Ingles, J., \& Neal. R. (1984). Application to shrimp stocks of objective methods for the estimation of growth, morlality, and recruitment related parameters from lemgth frequency data (ELEFAN I and II) (p. 220-234). In Penaeid ShrimpTheir Biology \& Management. Fishing News Book Limited. Farnham-Surrey-England.

Perez, R.N., Roman, A.M., \& Riovera, G.A. (1992). Investigation of the reproductive dynamic and preliminary evaluation of landings data of the dolphinfish Coryphaena hippurus, L. Final Report for Dingell-Johnson Project F26-1. Puerto Rico. Department of Natural Resources Fishery Research Laboratory Mayaguez. p. 95.
Potoschi, A. Reñones, O., \& Cannizzaro, L. (1999). Sexual development, maturity and reproduction of dolphinfish (Coryphaena hippurus) in the western and central Mediterranean. Sci. Mar., 63 (3-4), 367372.

Smallwood, C. B., Hesp, S.A., \& Beckley, L.E. (2013). Biology, stock status and management summaries for selected fish species in south-western Australia (p. 180). Fisheries Research Report No. 242. Department of Fisheries, Western Australia.

Sparre, P. \& Venema, S.C. (1998). Introduksi pengkajian ikan tropis (p. 438). Buku 1: Manual. Terjemahan. Pusat Penelitian dan Pengembangan Perikanan. Jakarta.

Suman, A., \& M. Boer. (2005). Ukuran pertama kali matang kelamin, musim pemijahan, dan parameter pertumbuhan udang dogol (Metapenaeus ensis de Haan) di perairan Cilacap dan sekitarnya. J. Lit. Perik. Ind. 11(2), 69-74.

Schwenke, K.L., \&. Buckel, J.A. (2007). Age, growth, and reproduction of dolphinfish (Coryphaena hippurus) caught off the coast of North Carolina. Fish. Bull. 106:82-92.

Triharyuni, S., \& Prisantoso, B.I. (2012). Komposisi jenis dan sebaran ukuran tuna hasil tangkapan longline diperairan Samudera Hindia selatan Jawa. Jurnal Saintek Perikanan. 8(1), 52-58.

Uchiyama, J.H., \& Boggs, C.H. (2006). Length-weight Relationships of Dolphinfish, Coryphaena hippurus, and Wahoo, Acanthocybium solandri: Seasonal Effects of Spawning and Possible Migration in the Central North Pacific. Mar. Fish. Rev. 68, 19-29.

UNEP. (2005). Vantier, L., Wilkinson, C., Lawrence, D., and D. Souter (eds.) Indonesian Seas, GIWA Regional assessment 57 (p. 160). University of Kalmar, Kalmar, Sweden. 
Weatherley, A.H. (1976). Factors Affecting Maximization of Fish Growth. Journal of the Fisheries Research Board of Canada, 33(4), 10461058.
Williams, P. (2014). Scientific Data Available To The Western And Central Pacific Fisheries Commission. Technical And Compliance Committee Tenth Regular Session 25 - 30 September 2014. Pohnpei, Federated States of Micronesia. www.wcpfc.int. 28 Juni 2016. 42 hal. 
Lampiran 1. Distribusi frekuensi panjang cagak ikan lemadang (Coryphaena hippurus) di PPS Bitung pada FebruaryDecember 2012

Appendix 2. Length frequency distribution of dolphin fish (Coryphaena hippurus) landed at Bitung OFP on February-December 2012

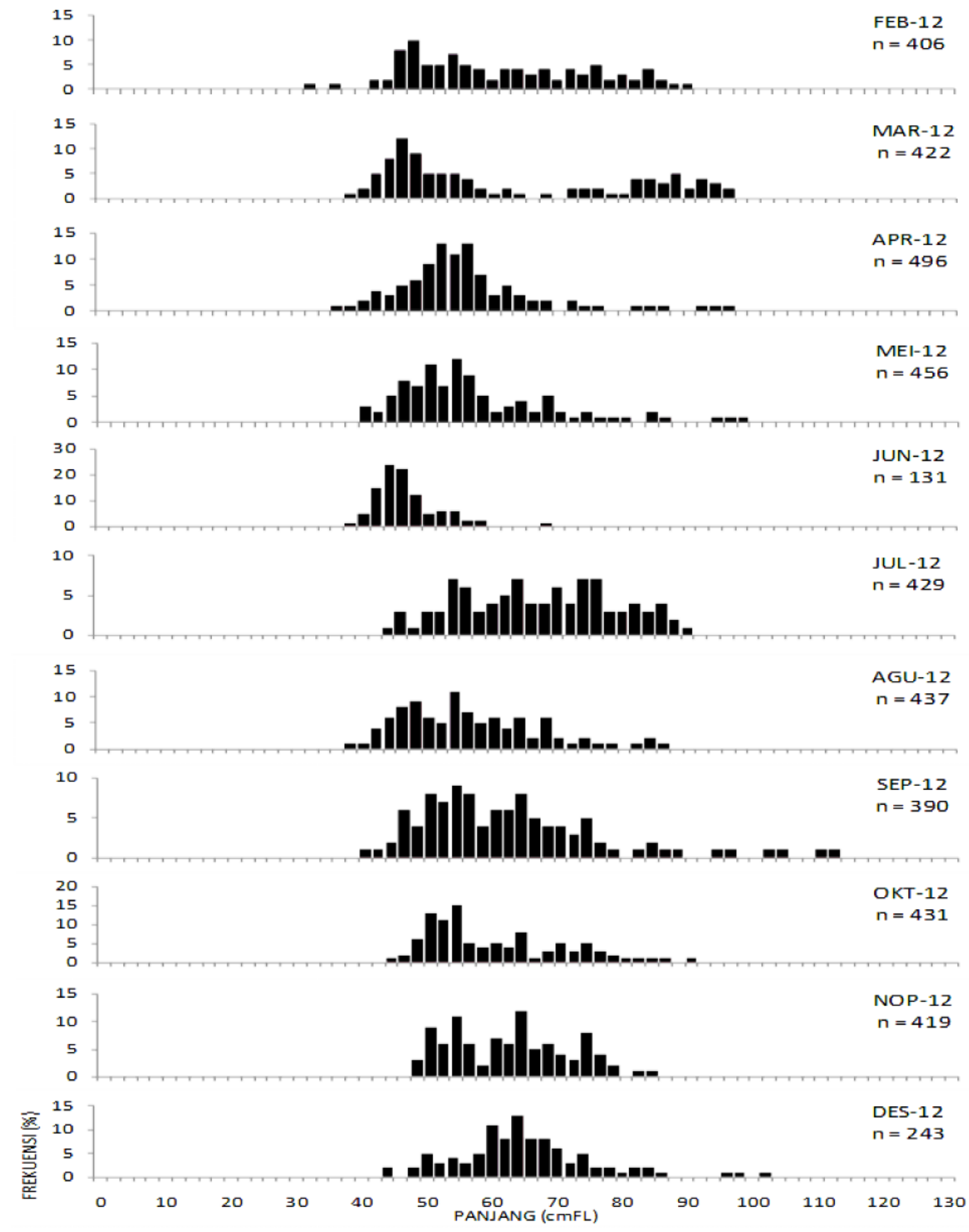

